\title{
Enzyme Immunoassay for Subgrouping Human Rotaviruses Using Monoclonal Antibodies
}

\author{
Osamu Nakagomi, Toyoko Kutsuzawa-Nakagomi, \\ Hajime Oyamada, Tsunehisa Suto and Atsuo Ochi* \\ Department of Microbiology and Department of Laboratory \\ Medicine, Akita University School of Medicine, Akita 010, \\ and *Department of Immunology, University of Tokyo, \\ Faculty of Medicine, Tokyo 113
}

\begin{abstract}
Nakagomi, O., Kutsuzawa-Nakagomi, T., Oyamada, H., Suto, T. and Ochi, A. Enzyme Immunoassay for Subgrouping Human Rotaviruses Using Monoclonal Antibodies. Tohoku J. exp. Med., 1984, 144 (1), 105-106 — Rotavirus groupspecific (common in human rotaviruses) and subgroup 1-specific monoclonal antibodies were established and an enzyme immunoassay was developed for subgrouping human rotaviruses.— enzyme immunoassay; subgroups; rotavirus; monoclonal antibodies
\end{abstract}

Rotavirus isolates have been typed into subgroups by complement fixation (Zissis and Lambert 1978), enzyme immunoassay (EIA) (Yolken et al. 1978) and immune adherence hemagglutination (Kapikian et al. 1981) using monospecific sera obtained by either absorbed hyper-immune serum or gnotobiotic calf postinfection serum. Since these antisera are difficult to obtain, developing monoclonal antibodies would be advantageous for use in these immunoassay systems.

We have fused spleen cells from mice immunized with KUN strain of rotavirus (Kutsuzawa et al. 1982) with X63-Ag8.653 cells to establish hybridoma clones which produce monoclonal antibodies reactive to rotaviruses. Two clones producing monoclonal antibodies, 133 and 152, were finally selected for use in an EIA for subgrouping. Wells of a microtiter plate were precoated with rabbit antibody directed against Wa virus. Test specimens containing rotaviruses were added to the wells in duplicate and incubated at $37^{\circ} \mathrm{C}$ for $2 \mathrm{hr}$. After washing with PBS containing Tween 20, monoclonal antibodies 133 and 152 were added to each well and incubated at $37^{\circ} \mathrm{C}$ for $2 \mathrm{hr}$. After washing, anti-mouse Ig conjugated with alkaline phosphatase was added and incubated at $37^{\circ} \mathrm{C}$ for $3 \mathrm{hr}$. After the final wash, p-nitrophenylphosphate was added and the color was measured at $405 \mathrm{~nm}$. The positive result was defined as the extinction value 3 standard deviations greater than the mean value of the negative controls.

We selected 20 human rotavirus strains and compared their subgroup specificities with antigenic titers measured by our EIA (Table 1). The subgroup specificity of these strains was determined by RNA electrophoresis. All the rotavirus strains reacted to the monoclonal antibody 152. Furthermore, all 152 rotavirus strains detected by a conventional EIA could be detected by the antibody 152. However, only subgroup 1 rotaviruses, KUN and $83 \mathrm{~A} 001$, reacted with a high titer to the monoclonal antibody 133 . Together with the

Received for publication, February 27, 1984. 
TABLE 1. Antigenic titers of 20 human rotavirus strains measured by monoclonal antibodies 133 and 152

\begin{tabular}{|c|c|c|c|}
\hline \multirow{2}{*}{ Virus } & \multirow{2}{*}{ Subgroup* } & \multicolumn{2}{|c|}{ Antigenic titer $†$} \\
\hline & & 133 & 152 \\
\hline KUN (culture fluid) & 1 & 4,096 & 2,048 \\
\hline Wa (culture fluid) & 2 & $<8$ & 256 \\
\hline MO (culture fluid) & 2 & $<8$ & 1,024 \\
\hline $82 \mathrm{~A} 003$ (5\% stool suspension) & 2 & $<10$ & 10,240 \\
\hline $83 \mathrm{~A} 001$ ( $5 \%$ stool suspension) & 1 & 10,240 & 2,560 \\
\hline $83 \mathrm{~A} 017$ (5\% stool suspension) & 2 & $<10$ & 1,280 \\
\hline $83 \mathrm{~A} 038$ (5\% stool suspension) & 2 & $<10$ & 640 \\
\hline $83 \mathrm{~A} 048$ ( $1 \%$ stool suspension) & 2 & $<10$ & 2,560 \\
\hline $83 \mathrm{~A} 051$ (5\% stool suspension) & 2 & $<10$ & 256 \\
\hline $83 \mathrm{~A} 053$ (5\% stool suspension) & 2 & $<10$ & 10,240 \\
\hline $83 \mathrm{~A} 054$ (5\% stool suspension) & 2 & $<10$ & 2,560 \\
\hline $83 \mathrm{~A} 058$ ( $5 \%$ stool suspension) & 2 & $<10$ & 640 \\
\hline $83 \mathrm{~A} 069$ (5\% stool suspension) & 2 & $<10$ & 1,280 \\
\hline $83 \mathrm{~A} 070$ (5\% stool suspension) & 2 & $<10$ & 2,560 \\
\hline $83 \mathrm{~A} 096$ (5\% stool suspension) & 2 & $<10$ & 1,280 \\
\hline $83 \mathrm{~A} 111$ (5\% stool suspension) & 2 & $<10$ & 160 \\
\hline 83 A119 (5\% stool suspension) & 2 & $<10$ & 10,240 \\
\hline $83 \mathrm{~A} 125$ (5\% stool suspension) & 2 & $<10$ & 320 \\
\hline $83 \mathrm{~A} 126$ (5\% stool suspension) & 2 & $<10$ & 1,280 \\
\hline $83 \mathrm{~A} 136$ (5\% stool suspension) & 2 & $<10$ & 2,560 \\
\hline
\end{tabular}

* Subgroup was determined by RNA electrophoresis.

$\dagger$ Reciprocals of the highest dilution giving positive EIA reading.

fact that these monoclonal antibodies reacted to the inner capsid particles $(1.38 \mathrm{~g} / \mathrm{ml}$ in $\mathrm{CsCl}$ ) of the rotavirus which were known to possess rotavirus group and subgroup antigens, we therefore concluded that the monoclonal antibody 152 was a antibody directed to the group antigen common to all human rotaviruses and that the monoclonal antibody 133 was specific to subgroup 1 rotaviruses. By using these two monoclonal antibodies, human rotavirus field isolates will easily be typed into subgroup 1 (reactive to both 152 and 133) or subgroup 2 (reactive to 152 but not to 133 ).

\section{References}

1) Kapikian, A.Z., Greenberg, H.B., Wyatt, R.G., Kalica, A.R., Banks, C.E., James, H. D., Flores, J. \& Chanock, R.M. (1981) Antigenic characterization of human and animal rotaviruses by immune adherence hemagglutination assay (IAHA). Infect. Immun., 33, 415-425.

2) Kutsuzawa, T., Konno, T., Suzuki, H., Kapikian, A.Z., Ebina, T. \& Ishida, N. (1982) Isolation of human rotaviruses subgroup 1 and 2 in cell culture. J. clin. Microbiol., 16, 727-730.

3) Yolken, R.H., Wyatt, R.G., Zissis, G., Brandt, C.D., Rodriguez, W.J., Kim, H.W., Parrot, R.H., Urrutia, J.J., Mata, L., Greenberg, H.B., Kapikian, A.Z. \& Chanock, R.M. (1978) Epidemiology of human rotavirus types 1 and 2 as studied by enzyme-linked immunosorbent assay. New Engl. J. Med., 299, 1156-1161.

4) Zissis, G. \& Lambert, J.P. (1978) Different serotypes of human rotavirus. Lancet, 1, 38-39. 